\title{
Development of Traditional Harmony-Based Teaching Materials Based on HOTS to Improve Student Musicality of Music Education Program at Language and Art Faculty at State University of Medan (UNIMED)
}

\author{
Uyuni Widiastuti ${ }^{1}$, Adina S Sembiring ${ }^{2}$, Muklis ${ }^{3}$, Hendy Obed Sembiring ${ }^{4}$, Ewin Johan \\ Sembiring ${ }^{5}$ \\ 1,2,3,4,5 Music Education Study Program, Faculty of Languages and Arts, Universitas Negeri Medan, \\ Indonesia \\ yuniyhundai@gmail.com
}

\begin{abstract}
The results of this study are: (1) The contents of teaching materials, are at an achievement of $88 \%$ with a valid category; (2)Constructor, achieving $84 \%$ with a valid category; (3) Language, on the achievement of 82.50 with a valid category (4) Display of teaching materials, on the achievement of $88 \%$ with a valid category. The results of the assessment of students consisted of: (1) the display of teaching materials was at an achievement of $87.87 \%$ with the practical category; (2) user convenience is at 85.52 with a practical category; (3) effectiveness in achieving 67.18 with a very practical category; (4) time effectiveness, in the achievement of 84.69 with the practical category, with an average value of achievement of 86.31 with the practical category.
\end{abstract}

Keywords: Teaching materials; traditional harmony; HOTS; musicality.

\section{Introduction}

The curriculum is one component to produce achieving learning, in addition to other components that support learning outcomes are: educators, students, learning methods, learning media and learning materials. Teaching materials are subject matter that will be delivered by educators to students in the form of written and unwritten materials. Therefore educators must be able to compile the teaching materials that will be used in the learning they teach. Good teaching materials will include: student instructions (student/ teacher instructions), the achievement competence, learning content or quizzes, supporting information, exercises, work instructions, can be in the form of Worksheet, and the evaluation of responses or to evaluation.

Teaching material is one of the important parts in the learning process. Teaching materials should be designed and written according to the rules of learning, i.e. adapted to learning materials, arranged based on learning needs, there are evaluation materials, and the instructional materials are interesting for students to learn. Dick and Carey (2009: 230) add that instructional material contains the content either written, mediated, or facilitated by an instructor that a student as use to achieve the objective also includes information about the learners will use to guide the progress. Based on the expressions of Dick, Carey, and Carey it can be seen that teaching materials contain content that needs to be learned by students either in the form of print or which are facilitated by teachers to achieve certain goals. Furthermore, Koesnandar (2008), the type of teaching materials based on the subject consists of two types between others: (a) teaching materials that are deliberately designed for learning, such as books, handouts, worksheets and modules; (b) teaching materials that are not designed but can be used for learning, for example clippings, newspapers, films, advertisements or news. Koesnandar also stated that when viewed from its function, the instructional material that was 
designed consisted of three groups namely presentation material, reference material, and independent learning material.

Teaching materials must also contain a high analytical skill called HOTS (Higher Order Thinking Skill), so that students can analyze important matters. HOTS is a concept of Benjamin Bloom that starts from the lowest to the highest. This concept is a learning goal that is divided into three domains, namely Cognitive (knowledge), Affective (attitude), and Psychomotor (skills). Bloom's taxonomic concept starts from the lowest: C1: remembering, $\mathrm{C} 2$ understands, and applies, while the highest starts from C4: analyzing, C5: evaluating and C6: creating. HOTS-based teaching materials will assist students in solving any problems in learning because they are accustomed to thinking at a high level. The objectives of this study are (1) Generating HOTS-based Harmony teaching materials; (2) Knowing the development of HOTS-based Harmony teaching materials can improve the musicality of FBS Unimed Music Education Study Program students.

Higher-order thinking skills (HOTS) are complex thought processes in breaking down material, making conclusions, building representations, analyzing and building relationships by involving the most basic mental activities, Resnick (1987) in Afandi (2017: 100). According to Smith (1993) in Sani Ridwan (2019: 2) high-level thinking will occur if someone has information stored in memory and obtains new information, then connects and collects and develops the information to achieve a goal or obtain answers/ possible solutions for a confusing situation. HOTS show an understanding of information and reasoning rather than just remembering information. The teacher is not only tests memory, so it is sometimes necessary to provide the information needed is to answer questions and students show understanding of ideas, information and manipulating or using that information. Other activities techniques can develop students' critical and creative thinking skills in the form of answering innovative questions.

Bloom refers to a taxonomy created for educational purposes known as Bloom's Taxonomy, which consists of several domains (domains, regions) and each of these domains is subdivided into more detailed divisions based on their hierarchy: (a) Knowledge; (2) Comprehension; (3) Application; (4) Analysis. (5) Synthesis (Synthesis); (6) Evaluation. Harmony is one of the courses in the Music Education Study Program included in the Study Area KDBK (Expertise Lecturer Group). In general, the description of Traditional Harmony courses is to arrange chords into harmonious melodies. The harmony in question is the arrangement of the soprano, alto, tenor and bass sounds into melodic progressions. According to Pono (2003:16) harmony is: harmony, beauty. Harmony will be formed in two possibilities, namely in harmony or not in harmony, beautiful or not beautiful. The Harmony course consists of two semesters namely Traditional Harmony (odd semester) and Modern Harmony (Even semester).

The material learned in Traditional Harmony includes notes, intervals and chords (original chord, feedback loop I, feedback loop II, V7 chord along with feedback I/II/III, V9 chord with feedback I/II, V13 chord and feedback I/II and non-chords). All of this material is the basis for arranging (changing) songs for soprano, alto, tenor and bass sounds.

Some people refer to musical intelligence as musical intelligence. People who have this type of intelligence are very sensitive to sound or sound, the environment and also music. They often sing, whistle or hum when doing other activities. They love listening to music, collecting cassette/CD songs, and can play musical instruments. They sing using the right chords and are able to remember and vowels and can reproduce melodies. They can move 
rhythmically when accompanying music or accompanying activities or making rhythms and songs to help them remember facts and other information.

Musicality is the ability to perceive (for example music lovers), differentiate (for example, as a music critic), change (for example, as a music composer) and express (for example, as a performer or music player) musical forms. This intelligence includes sensitivity to rhythm, tone or melody, and timbre or color tone in a piece of music. Someone can have a figural understanding of music or "from the top down" (global, intuitive), a formal understanding of music or "from the bottom up" (analytical, technical) or both, Armstrong (2013: 7).

\section{Research Methods}

\section{A. Research Type}

This research uses a type of research and development or Research and Development (R\&D) which is usually good enough to improve learning. The development research model used in this study is the Four-D Model from Sivasailam Thiagarajan, Dorothy S. Semmel, and Melvyn (1974). This model consists of 4 stages: Define, Design, Develop and Disseminate.

\section{B. Research Procedures}

This 4-D model consists of 4 stages, namely: Define, Design, Develop and Disseminate or be adapted to become a 4-D model, namely: (1) Define Phase is the stage for defining and defining learning requirements; (2) Design Phase (design) aims to design learning tools; (3) Develop (Development) is the stage to produce development products which are carried out through two steps, namely: expert assessment and development testing (developmental testing); (4) Disseminate, the process of dissemination is a final stage of development.

\section{Data Collection Techniques}

This development research uses techniques in data collection, namely:

\section{Validation}

Validators are asked to provide improvements and suggestions for teaching materials. If the validation results are not yet valid, teaching materials will be improved until teaching materials are truly valid and perfect for use in Traditional Harmony learning.

2. Practicality

After validation by two validators, teaching materials are then tested on users (students), which aims to find out the practicalities in the process of learning traditional harmony.

\section{Trial}

Subjects in the trial of Traditional Harmony teaching materials are Regular Class A class 2017 students who are now in semester III of FY 2019/2020, with the criteria that the class has never used Traditional Harmony teaching material.

\section{E. Data Analysis Techniques}

\section{Validity Data Analysis}

The questionnaire results data obtained from lecturers and students are used to compile the background and determine the level of need for the product being developed. Data on the 
suitability of instructional materials and design of instructional materials was obtained from material experts and design experts through expert validation tests. Expert validation data is then used to determine the feasibility of the product produced, using the formula:

Validity $=\underline{\text { Score obtained }} \times 100$

\section{Max score}

The level of achievement of the validity category of teaching materials uses the following classification:

Table 1. Categories of Validity Levels of Teaching Materials

\begin{tabular}{|l|l|l|}
\hline No & Achievement (\%) & Category \\
\hline 1 & $90-100$ & Very valid \\
\hline 2 & $80-89$ & Valid \\
\hline 3 & $65-79$ & Pretty valid \\
\hline 4 & 55064 & Less valid \\
\hline 5 & $0-54$ & Very invalid \\
\hline
\end{tabular}

Furthermore, analyzing the practicality of teaching materials based on a questionnaire given to students. The questionnaire was prepared using a Likers scale so the scores for each answer were used, using the following formula:

Value of Practicality $=\underline{\text { Number of scores obtained }} \times 100$

Highest score amount

Table 2. The Level of Practicality

\begin{tabular}{|l|l|l|}
\hline No & Achievement (\%) & Category \\
\hline 1 & $86-100$ & Very Practical \\
\hline 2 & $80-89$ & Practical \\
\hline 3 & $65-79$ & Pretty Practical \\
\hline 4 & $55-64$ & Less Valid \\
\hline 5 & $0-54$ & Very Unpractical \\
\hline
\end{tabular}

Furthermore, analyzing the practicality of teaching materials based on a questionnaire given to students. The questionnaire was prepared with using Likers scale so the scores for each answer were used, using the following formula:

Value of Practicality $=\underline{\text { Number of scores obtained }} \times 100$

Highest score amount 
Table 3. Practical Level of Teaching Materials

\begin{tabular}{|l|l|l|}
\hline No & Achievement (\%) & Category \\
\hline 1 & $86-100$ & Very Practical \\
\hline 2 & $80-89$ & Practical \\
\hline 3 & $65-79$ & Pretty Practical \\
\hline 4 & $55-64$ & Less Valid \\
\hline 5 & $0-54$ & Very Unpractical \\
\hline
\end{tabular}

\section{Discussion}

\section{A. Traditional Harmony-Based Instructional Materials HOTS}

The teaching materials in Music Education Study Program must be adapted to the needs of students to be applied in the schools. Therefore teaching materials developed by lecturers must be in accordance with the needs of the school, although the development and modification can be done by music teachers who teach. Teaching materials must be arranged systematically and continuously in both the previous course and the subsequent courses, as in Traditional Harmony teaching material (semester III) must refer to the previous course, namely Music Knowledge (Semester I and II) as well as the next subject Modern Harmony (semester IV).

Traditional Harmony teaching materials should contain Higher Order Thinking Skills (HOTS), which consist of: (a) Analysis (Analysis); (b) Synthesis (Synthesis); (3) Evaluation. Traditional Harmony teaching materials contain the three HOTS described above, because all the material in Traditional Harmony teaching materials sharpens the brain to think in determining a series of melodic progressions in one musical sentence (measure of one to eight) to be arranged into song harmonization 4 homophonic sounds (soprano, alto, tenor and bass).

Traditional Harmony teaching material in Music Education Study Program is not only in the form of narration and exposure, there must be stimulation to improve student musicality in making harmonization of 4 homophonic sounds. Traditional Harmony courses are the basis for arranging songs, therefore students are guided starting from determining and composing chord notes to a series of chords in accordance with the rules that apply in arranging. This competency is very much needed later, both when becoming a teacher, especially practitioners, where after completing this lecture students are not only able to arrange children's songs that are very simple but can arrange songs using modern chords (Harmoni Modren courses) so that they meet stakeholder requests and needs. Teaching materials generally contain:

1. Learning objectives contain the final results on each material to be taught which must be mastered by students.

2. Description of the material, containing exposure to material adapted to the Semester Learning Plan (RPS)

3. Summary, expanding conclusions from a number of material that has been presented to facilitate students understanding the material 
4. Exercise, containing practice questions that must be done by students and will be presented every week before the next material is given by the lecturer.

Specifically in the given practice questions, each student has different answers, according to the musicality present in each student, therefore the more often students work on the practice questions, the musicality will increase in each student.

\section{B. Development of HOTS-Based Harmony Teaching Materials to Improve the Musicality of Students of Music Education Study Program at Language and Art Faculty of State University of Medan (UNIMED)}

The development of teaching materials includes 4 stages known as the 4-D model, namely: Define, Design, Develop and disseminate, but in this study only three stages are Define, Design and Develop alone.

\section{Define}

The first step taken in the development of Traditional Harmony teaching materials is to establish and define the terms of learning carried out through five steps, namely:

a. Front-end analysis

At this stage, the lecturer makes an initial diagnosis to students to improve the efficiency and effectiveness of Traditional Harmony learning. The results of the analysis found that the learning carried out so far was only in the form of face-to-face lecture methods. Assignments given to students are limited to theoretical assignments. Whereas in harmony there is a need for sounds through the media (vocal or piano) to hear the results of chord progressions. So the tasks that have been arranged by students must be sounded (sung with 4 voices) so that the assignment is not only correctly following the rules (laws) that apply in harmony but still harrmonist to be heard.

b. Student analysis (learner analysis)

At this stage the lecturer looks at the characteristics of students: the abilities students have before learning Traditional Harmony, namely: in the Knowledge of Music course in semester I and semester II.

This analysis found that:

1). Students cannot read with beam notation especially notation on key F.

2). Students cannot read with beam notation in chromatic tone

3). Students have not been able to determine the basic notes on the scale

4). Students have not memorized major and minor scales

5). Students cannot put notes on the G key and F key

6). Students do not yet know the soprano, alto, tenor, bass sound registers

7). Students do not know the notes on the chords

8). Students do not know the interval (distance, name, type, etc.)

Some of these findings are material obtained in Music Knowledge courses, and it turns out that many students do not understand the material, thus hampering the provision of material in Traditional Harmony courses. The solution taken by the lecturer is to provide the material at the second and third meetings, so as to disrupt the next meeting. This is done because the material (scales, intervals, chords) is the basis for forming the chords used in harmony. 
c. Task Analysis

At this stage the lecturer analyzes the Traditional Harmony course assignments that students must master so students can achieve minimal competence. The assignments given to students have been separated from the assignments in the first, second, third and so on. Though all the tasks that exist in all material are closely related and continue to be used in subsequent assignments. In addition, the assignments given only contained material given at the meeting. When the tasks in the fourth material should be given, it must include the tasks that have been given in the first, second and third material so that all tasks are mutually sustainable.

d. Concept Analysis

At this stage the lecturer analyzes the concept of Traditional Harmony to be taught as well as arranging learning steps that will be carried out mechanically and rationally. The results of the analysis on the provision of material obtained that: the material given to students has been separated from the first material, second, third and so on, even though all the material is very related and continuous use in the next material. Therefore the material presented must be systematic so that every rule in harmony can be followed.

e. Formulation of Learning Objectives (specifying instructional objectives)

At this stage the lecturer writes the learning objectives as well as the expected behavioral change after learning Traditional Harmony. During this time the lecturer never conveyed the learning objectives, so students did not know the learning achievements provided. Therefore, before learning is given, the lecturer must convey the learning objectives in accordance with the material provided, so that students know the abilities they have after learning is done.

\section{Design}

The second step taken in the development of Traditional Harmony teaching materials to design learning tools is carried out through four steps, namely:

a. Preparation of Test Standards (criterion-test construction)

The lecturer takes the first action to find out the initial ability of students in Traditional Harmony courses and as an evaluation tool after the implementation of Traditional Harmony learning. The initial test was conducted at the first meeting and the test instrument contained material on music knowledge as a basis for determining students' ability to obtain material available in Traditional Harmony courses. While the final test is conducted at the eighth meeting (Mid Semester Examination) to see the results of learning Traditional Harmony.

b. Media selection

In the selection of instructional media for Traditional Harmony courses, the lecturer adapts the learning media to the material characteristics, learning objectives, and student characteristics. Traditional Harmony Learning is not only presented with the provision of material in theory, but must also be practiced to sound the results of the preparation of chords progression. Therefore it is necessary to have a demonstration to sound it well with sound media conducted in groups (4 votes). If in one group cannot sing it correctly, it can be done by playing four types of instruments according to the type of sound written on the sheet music. 


\section{c. Format selection}

The lecturer examines the existing Harmoni Traditional teaching material formats and determines the format of the Traditional Harmony teaching material to be developed. The choice of form of presentation of learning is adjusted to the learning media used. Formats that will be used in the development of Traditional Harmony teaching materials include:

1). Preliminary
a) Subject identity
b) Course Description
c) Prerequisite Competencies
d) Lecturer Qualifications
e) Competency standards
f) Basic competencies
g) Indicator
h) Sofskill Attribute
i) Subject
j) Learning Activity
k) Task
1) Evaluation
m) Learning Resources

2. Material
a). preliminary
b). Theory
c). Summary
d). Task
e). References

d. Make an initial design

The lecturer simulates the presentation of Traditional Harmony material with the media and learning steps that have been designed. When the Traditional Harmony learning simulation takes place, the lecturer evaluates from peers (between students).

\section{Develop (Development)}

The third step is taken in the development of Traditional Harmony teaching materials to produce product development is carried out through two steps, namely:

a. Validation

Validation of Traditional Harmony teaching materials is carried out by experts in the field of developing Traditional Harmony teaching materials and materials at Medan State University, namely: Dr. Surya Masniari Hutagalung, M.Pd for teaching materials, and Erizon, S.Sn, M.Sn for the Traditional Harmony material field. In general, the experts gave several suggestions for the improvement of Traditional Harmony teaching materials and the improvement of the draft teaching materials that were prepared.

Let me explain the results of the validation sheet revision from the validator: 
Table 4. The result Revision of Validator

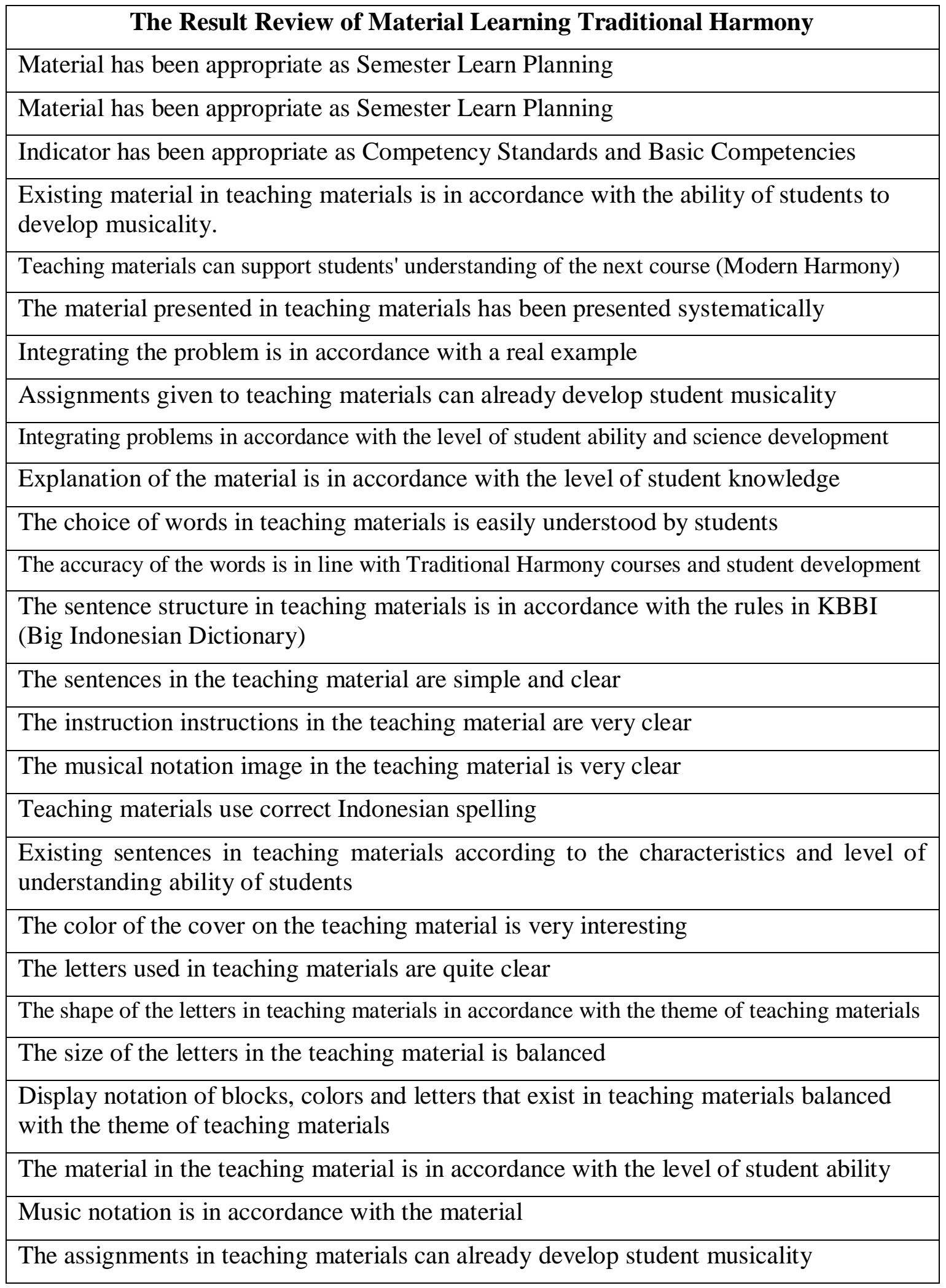




\begin{tabular}{|l|}
\hline All materials have been given concrete examples \\
\hline Bibliography in the teaching materials are in accordance with teaching materials \\
\hline Teaching materials have been arranged systematically and continuously \\
\hline Reference books are already using foreign authors \\
\hline Reference books should use more last year (updated) \\
\hline Each material already contains an introduction that contains the material to be studied \\
\hline
\end{tabular}

After being revised, Validator gives a score for the teaching material and then analyzes the data, which can be seen in the following table:

Table 5. Validator Assessment Results

\begin{tabular}{|l|l|c|c|}
\hline No & Variable & Achievement (\%) & Category \\
\hline 1 & Fill in teaching materials & 88 & valid \\
\hline 2 & The structure & 84 & valid \\
\hline 3 & Language & 82,50 & valid \\
\hline 4 & Display of teaching materials & 88 & valid \\
\hline \multicolumn{2}{|c|}{ Average } & 85,62 & valid \\
\hline
\end{tabular}

The results of the assessment of the two validators consisted of three variables, namely: (1) The content of teaching materials, was at the achievement of $88 \%$ with a valid category; (2) Constructor, achieving $84 \%$ with a valid category; (3) Language, on the achievement of 82.50 with a valid category (4) Display of teaching materials, on the achievement of $88 \%$ with a valid category. For more details can be seen in the following graph (Figure 1.)

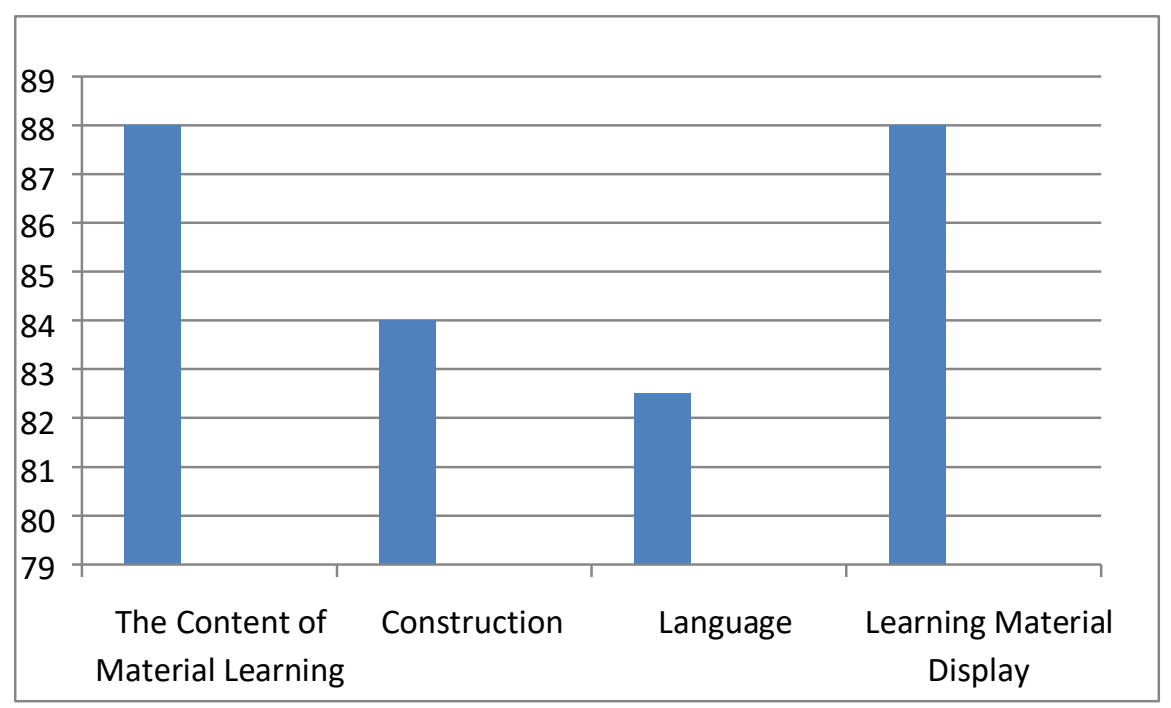

Figure1. The results of the assessment of two validators 


\section{b. Trial of Teaching Materials}

This activity is a trial design of Traditional Harmony teaching materials and the actual target subject (students). When testing Traditional Harmony teaching materials, response data, reactions and comments from users of teaching materials (students) are sought, and the results are used to improve teaching materials. The trial was conducted in Class A Regular class of 2018 (semester III) Music Education Study Program at the Faculty of Language and Arts Unimed. The purpose of this trial is to assess the practicality of teaching materials that can be seen from the activeness of students during the learning of Traditional Harmony, but it also can improve student musicality. The following will be presented the results of a trial of teaching materials from students:

Table 6. Student Practicality Results

\begin{tabular}{|c|l|c|c|}
\hline No & \multicolumn{1}{|c|}{ Variabel } & Achievement (\%) & Category \\
\hline 1 & Display teaching materials & 87,87 & Practical \\
\hline 2 & User convenience & 85,52 & Practical \\
\hline 3 & Usability & 87,18 & Practical \\
\hline 4 & Time effectiveness & 84,69 & Practical \\
\hline \multicolumn{2}{r|}{ Average } & 86,31 & Practical \\
\hline
\end{tabular}

The results of the assessment of students consisted of three variables, namely: (1) the display of teaching materials was at an achievement of $87.87 \%$ with the practical category; (2) user convenience is at 85.52 with a practical category; (3) effectiveness in achieving 67.18 with a very practical category; (4) time effectiveness, in the achievement of 84.69 with the practical category, with an average value of achievement of 86.31 with the practical category. For more details, you can see in the following chart (Figure .2):

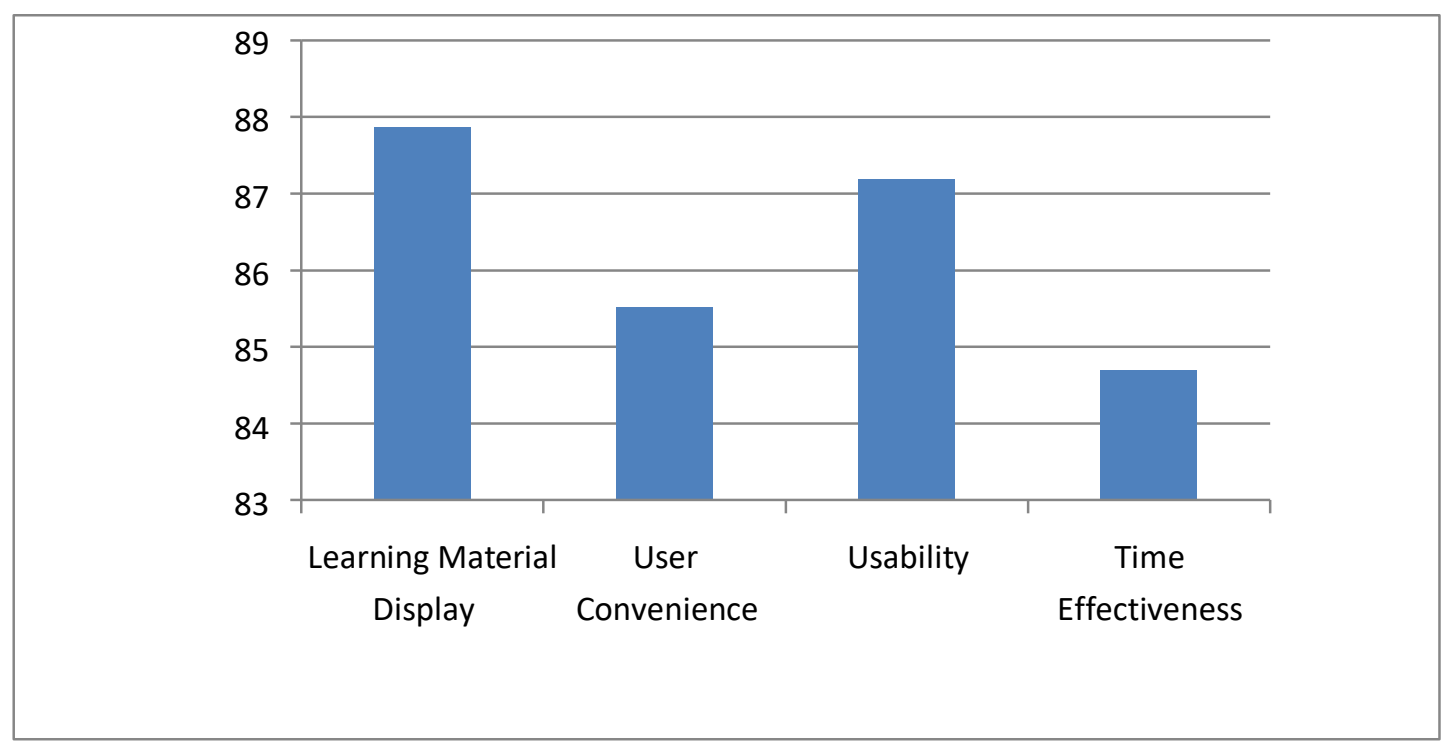

Figure 2. The results of the assessment of student 


\section{Conclusion}

The conclusion of this research is to use the 4-D Model, namely: Define, Design, Develop and Disseminate, the development of HOTS-based Traditional Harmony teaching materials can improve the musicality of students at the FBS Unimed Music Education Study Program. This is evidenced by the results of the assessment of the validator consisting of three variables, namely: (1) The contents of teaching materials, are at an achievement of $88 \%$ with a valid category; (2) Constructor, achieving $84 \%$ with a valid category; (3) Language, on the achievement of 82.50 with a valid category (4) Display of teaching materials, on the achievement of $88 \%$ with a valid category. The results of the assessment of students consisted of three variables, namely: (1) the display of teaching materials was at an achievement of $87.87 \%$ with the practical category; (2) user convenience is at 85.52 with a practical category; (3) effectiveness in achieving 67.18 with a very practical category; (4) time effectiveness, in the achievement of 84.69 with the practical category, with an average value of achievement of 86.31 with the practical category. So that it can be said that Traditional Harmony teaching materials are appropriate to be used in Traditional Harmony learning courses.

\section{References}

Amstrong, (2013). Kecerdasan Multipel di Dalam Kelas. $3^{\text {rd }}$ Edition. Jakarta: PT Indeks Afandi. (2018), Stimulasi Keterampilan Berpikitr Tingkat Tinggi, Semarang: UNS Press

Dick and Carey (2009), Dick, W and L. Carey, J. O. Carey. 2005. The systematic Design of Instruction. New York : Logman.

Koesnandar. (2008). Modul Pemanfaatan TIK untuk Pembelajaran. Jakarta:Pusat Teknologi Informasi dan Komunikasi Pendidikan

Pono, Banoe, (2003). Pengantar Pengetahuan Harmoni, Yogyakarta: Karnisius.

Sivasailam Thiagarajan, Dorothy S. Semmel, and Melvyn I. Semmel (1974). Model Pengembangan dan Pembelajaran. https://ayahalby.files.wordpress.com/2012/10/ konsep-pengembangan-danpembelajaran-modul.pdf. Accesed on 28 April (2016)

Sani Ridwan. (2019). Pembelajaran Berbasis HOTS. Jakarta: TS Smart 